\title{
KAJIAN PENGARUH KERJASAMA PERDAGANGAN INDONESIA - CHILE TERHADAP PENINGKATAN PERDAGANGAN INDONESIA DI WILAYAH ASIA PASIFIK
}

\author{
Victor Tulus Pangapoi Sidabutar ${ }^{1}$ \\ ${ }^{1}$ Balai Besar Pendidikan dan Pelatihan Ekspor Indonesia, Jl. Letjen S Parman No. 112 Grogol, Jakarta 11440, \\ Indonesia
}

\begin{abstract}
Trans-Pacific Partnership (TPP) is a trade agreement between the twelve countries in Asia Pacific region with the aim to encourage the liberalization of trade in member countries, especially in terms of tariffs, trade protection, and economic equality. Indonesia indicated its intention to enter the TPP in order to expand the market share of Indonesian exports. Indonesia currently has trade agreements with almost all countries with TPP members, except with Chile, as one of them. The analysis was done by analyzing Indonesia-Chile's trade in 2011 to 2015; analyze Chile's trade with Canada, Singapore, and Vietnam and also based on the results of simulations by Petri (2016). The simulation results show that agreement can be beneficial TPP countries involved in it, seen with increasing GDP of member countries. In addition, TPP also increases the flow of inward investment more than outward investment, especially investment coming from countries with the high economy. But the free trade agreement (FTA) Indonesia with major trading partners should also be considered before Indonesia joint TPP.
\end{abstract}

Key Words : Agreement, Trans-Pacific Partnership (TPP).

\section{PENDAHULUAN}

Rencana Strategis Kementerian Perdagangan Tahun 2015 - 2019 (2015) diantaranya adalah memperluas pangsa pasar ekspor di pasar prospektif dan hub perdagangan Internasional. Saat ini Indonesia terus melakukan negosiasi dan kesepakatan multilateral, regional dan bilateral dalam upaya untuk mengimbangi dinamika perekonomian dunia cenderung semakin cepat dan mengubah peta perdagangan dunia secara mendasar. Salah satu forum bilateral yang penting dalam tahapan negosiasi adalah kerjasama dengan Chile. Chile merupakan salah satu negara anggota Trans-Pacific Partnership (TPP) yang terdiri dari Amerika Serikat (keluar di 2017), Jepang, Kanada, Australia, Meksiko, Malaysia, Singapura,
Chile, Vietnam, Peru, Brunei dan Selandia Baru. Jika dilihat dari seluruh anggota TPP, Indonesia memiliki kerjasama ekonomi dan perdagangan dengan hampir seluruh negara anggota TPP, kecuali dengan negara Kanada, Meksiko, Chile dan Peru.

Pembicaraan awal kerjasama Indonesia dengan Chile dimulai tahun 2008 dimana dijajaki dilakukan kerjasama Indonesia - Chile Free Trade Agreement. Kemudian negosiasi pertama telah dilaksanakan pada tanggal 2627 Mei 2014 di Santiago, Chile. Pembahasan dilakukan bertahap dimulai dengan Trade in Goods. Kerjasama antar keduanya diusulkan dalam bentuk Comprehensive Economic Partnership Area (CEPA).

Diharapkan dengan terbentuknya kerjasama Indonesia - Chile maka dapat 
membuka pintu gerbang perdagangan Indonesia ke Negara di Benua Amerika lainnya sehingga tujuan dari Renstra Kemendag dapat tercapai.

\section{METODE}

Permasalahan yang akan dipecahkan pada penelitian ini adalah dengan melihat potensi perkembangan perdagangan ekspor dan impor Indonesia ke Chile dengan melihat hasil simulasi yang dilakukan Petri (2016) dengan hanya memperhitungkan faktor ekonomi, meskipun pengaruh dari geopolitik juga penting. Analisis Petri (2016) untuk menghasilkan penilaian kuantitatif mengenai integrasi TPP dan Asia-Pasifik menggunakan model analisis Computerable General Equilibrium (CGE) dihitung berdasarkan interaksi antara perusahaan, rumah tangga, dan pemerintah pada beberapa pasar produk di beberapa daerah ekonomi dunia. Perusahaan dan konsumen diasumsikan memaksimalkan keuntungan dan kesejahteraan terhadap harga. Selain itu, digunakan juga data sekunder mengenai data-data perdagangan ekspor dan impor, pengamatan kenaikan transaksi ekspor dan impor terhadap perubahan tarif dan pengamatan perkembangan komoditi yang diperdagangkan dalam skema FTA yang Indonesia miliki saat ini.

\section{PERKEMBANGAN PERDAGANGAN INDONESIA}

Berdasarkan data dari BPS (2016), ekspor Indonesia pada Januari - Agustus 2016 mencapai volume 329.974,9 ribu ton dengan nilai USD 91.846,4 juta, yang terdiri dari USD 8.634,9 juta hasil ekspor minyak bumi dan gas dan USD 83.211,4 juta hasil ekspor komoditi nonmigas. Dibandingkan periode yang sama tahun 2015, nilai ekspor tahun 2016 turun USD 10.770,5 juta karena adanya penurunan ekspor migas senilai USD $4.309,9$ juta. Demikian juga dari kelompok nonmigas menurun USD $6.460,7$ juta atau turun 7,20 persen dibanding periode yang sama tahun sebelumnya. Pada Agustus 2016 harga minyak mentah Indonesia USD 41,11 per barelnya, turun sebesar USD 1,70 per barel dibandingkan Agustus 2015 terjadi penurunan ekspor Indonesia saat ini.

Dipandang dari negara tujuan ekspor, BPS (2016) mencatat pada Agustus 2016 ekspor migas yang ditujukan ke kawasan Asia Timur dan Asia Selatan \& Tenggara tercatat USD 580,9 juta dan USD 449,1 juta, menurun dibanding tahun 2015 seperti terlihat pada Tabel 1. Negara yang memperlihatkan penurunan ekspor migas adalah Tiongkok dengan persentase penurunan 38,78 persen, Jepang dengan persentase penurunan 20,81 persen, dan Singapura dengan persentase penurunan 38,17 persen. Sedangkan Thailand dan Malaysia memperlihatkan peningkatan dibanding tahun 2015, dengan persentase peningkatan masing-masing 14,83 persen dan 0,56 persen. Dari Tabel 1 juga terlihat bahwa total ekspor migas pada Agustus 2016 menunjukkan penurunan 25,63 persen menjadi USD 1.138,6 juta. 
Tabel 1

Perkembangan Ekspor Migas dan Nonmigas Indonesia Menurut Negara Tujuan, Agustus 2015 dan Agustus 2016 (Juta USD)

\begin{tabular}{|c|c|c|c|c|c|c|}
\hline \multirow[b]{2}{*}{$\begin{array}{l}\text { Kawasan Negara } \\
\text { Tujuan Ekspor }\end{array}$} & \multicolumn{3}{|c|}{ Migas } & \multicolumn{3}{|c|}{ Nonmigas } \\
\hline & $\begin{array}{l}\text { Agustus } \\
2015\end{array}$ & $\begin{array}{l}\text { Agustus } \\
2016\end{array}$ & $\begin{array}{c}\text { Perubahan } \\
\text { (\%) }\end{array}$ & $\begin{array}{l}\text { Agustus } \\
2015\end{array}$ & $\begin{array}{l}\text { Agustus } \\
2016\end{array}$ & $\begin{array}{c}\text { Perubahan } \\
\text { (\%) }\end{array}$ \\
\hline Asia Timur & 859,7 & 580,9 & $-32,43$ & $3.196,6$ & $3.437,6$ & 7,54 \\
\hline Jepang & 309,5 & 245,1 & $-20,81$ & $1.046,4$ & $1.172,5$ & 12,05 \\
\hline Tiongkok & 172,5 & 105,6 & $-38,78$ & $1.111,5$ & $1.355,2$ & 21,93 \\
\hline $\begin{array}{l}\text { Asia Selatan \& } \\
\text { Tenggara }\end{array}$ & 540,5 & 449,1 & $-16,91$ & 3504,6 & 3819,2 & 8,98 \\
\hline Thailand & 111,9 & 128,5 & 14,83 & 396,3 & 413,1 & 4,24 \\
\hline Singapura & 317,8 & 196,5 & $-38,17$ & 721,3 & 751,3 & 4,16 \\
\hline Filipina & 0,0 & 0,0 & 0,00 & 404,3 & 580,1 & 43,48 \\
\hline Malaysia & 106,2 & 106,8 & 0,56 & 475,0 & 527,1 & 10,97 \\
\hline Asia Barat & 0,3 & 0,4 & 33,33 & 549,8 & 370,5 & $-32,61$ \\
\hline Afrika & 0,0 & 0,1 & - & 360,4 & 318,7 & $-11,57$ \\
\hline $\begin{array}{l}\text { Australia \& } \\
\text { Oceania }\end{array}$ & 53,3 & 61,0 & 14,45 & 373,4 & 282,8 & $-24,28$ \\
\hline Amerika Utara & 76,8 & 41,9 & $-45,44$ & $1.393,4$ & $1.423,5$ & 2,16 \\
\hline Amerika Serikat & 76,8 & 41,9 & $-45,44$ & 1330,9 & 1359,8 & 2,17 \\
\hline $\begin{array}{l}\text { Amerika Tengah \& } \\
\text { Selatan }\end{array}$ & 0,0 & 0,0 & - & 279,1 & 307,5 & 10,18 \\
\hline Eropa Barat & 0,3 & 5,2 & 1633,33 & $1.240,2$ & $1.356,0$ & 9,34 \\
\hline Eropa Timur & 0,0 & 0,0 & - & 297,6 & 293,9 & $-1,24$ \\
\hline Total Ekspor & $1.530,9$ & $1.138,6$ & $-25,63$ & $11.195,1$ & 11609,7 & 3,70 \\
\hline
\end{tabular}

IV. PROFILE NEGARA CHILE

Chile adalah dari anggota OECD (the Organisation for Economic Co-operation and Development) dan memiliki ekonomi terbuka dengan sejumlah besar perjanjian perdagangan regional atau bilateral. Chile telah melakukan diversifikasi jaringan perdagangan dan merupakan anggota dari Aliansi Pasifik. Perekonomian utamanya, berdasarkan data dari intracen (2014), bergantung pada ekspor tembaga, dengan sektor pertanian yang kuat. Di sektor perdagangan terdapat kebutuhan untuk mengurangi ketergantungan pada ekspor komoditas serta berupaya untuk meningkatkan daya saing UKM mereka. Human Development Index (HDI) Chile, berdasarkan data Human Development Report (2015) pada Gambar 1 dan 2, terus mengalami peningkatan dan bersaing dengan Argentina (Tabel 2) untuk sesama negara di Latin Amerika dan Karibian.

Nilai tambah penyumbang terbesar untuk GDP Chile menurut data dari worldbank (2016) terletak pada sektor pertanian, industri, manufaktur dan jasa (Tabel 3). 


\section{PERDAGANGAN INDONESIA KE CHILE}

Berdasarkan data trademap (2016), total impor Chile dari Indonesia (dalam ribu USD) 183.458 dengan $-7 \%$ pertumbuhan dari tahun 2011 hingga 2015 dan hanya $0.3 \%$ bagian dari total impor Chile. Equivalent ad valorem tariff yang diberikan Chile ke Indonesia rata-rata 6\% kecuali untuk HS Code 88 (2,2), $89(3,5)$ dan $49(5,5)$. Produk utama yang di impor adalah produk dengan HS Code 64 dengan nilai (dalam ribu USD) 47.785. Sedangkan untuk total impor Indonesia dari Chile (dalam ribu USD) 173.848 dengan $-13 \%$ pertumbuhan dari tahun 2011 hingga 2015 dan hanya $0.1 \%$ bagian dari total impor Indonesia. Equivalent ad valorem tariff yang diberikan Indonesia ke Chile bervariasi dari 0\% (HS Code 31) hingga tertinggi 89.9\% (HS Code 22). Produk utama yang di impor adalah produk dengan HS Code 74 dengan nilai (dalam ribu USD) 99.022 .

\section{Gambar 1}

Tren Indikator Komponen HDI Chile dari tahun 1980 hingga 2014

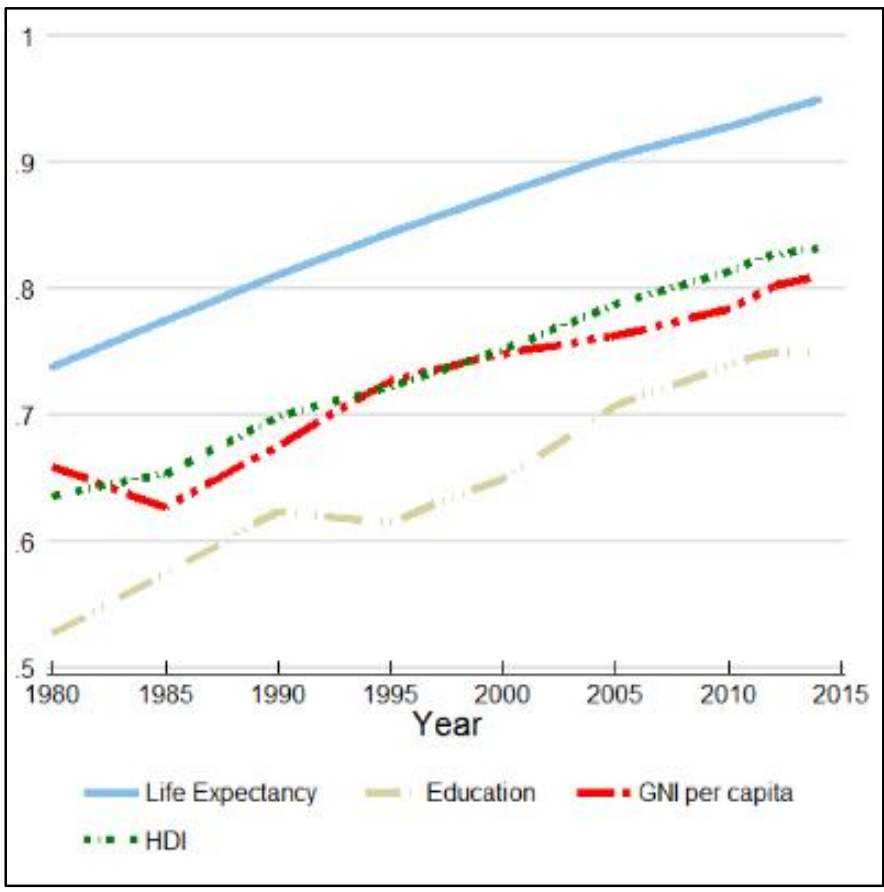

Sumber: Human Development Report (2015) 
Gambar 2

Tren HDI Chile, Kuba dan Venezuela dari tahun 1980 hingga 2014

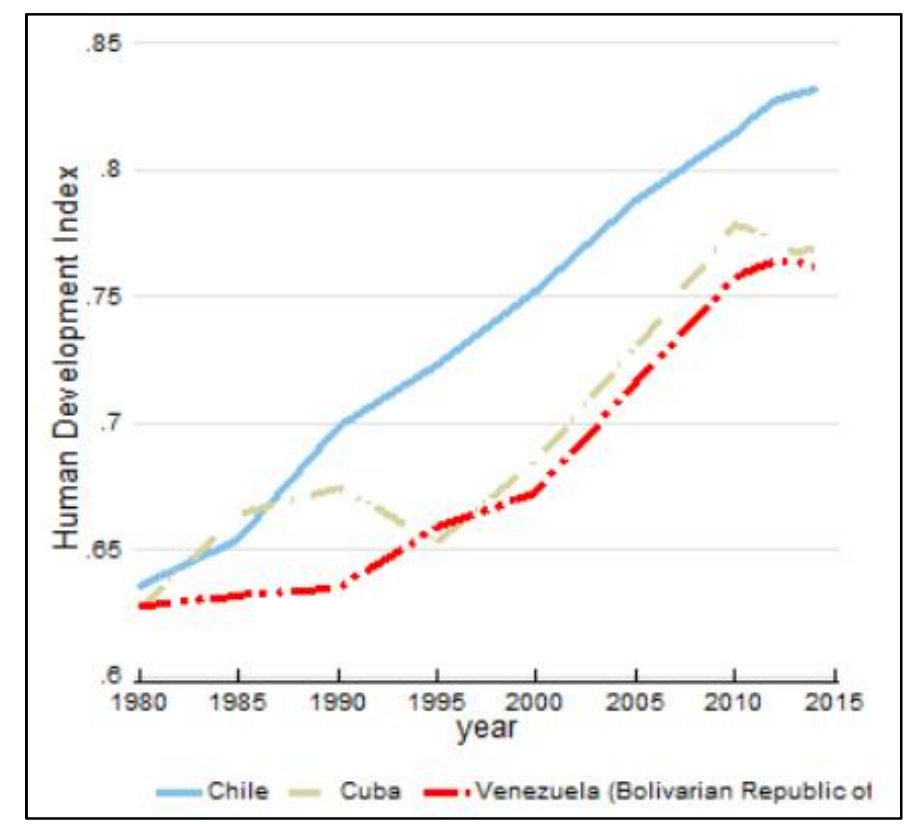

Sumber: Human Development Report (2015)

Tabel 2

Indikator HDI Chile tahun 2014 dibandingkan beberapa negara dan kelompok

\begin{tabular}{ccccccc}
\hline & Nilai HDI & $\begin{array}{c}\text { Peringkat } \\
\text { HDI }\end{array}$ & $\begin{array}{c}\text { Kemungkinan } \\
\text { hidup saat } \\
\text { lahir }\end{array}$ & $\begin{array}{c}\text { Tahun } \\
\text { diharapkan } \\
\text { bersekolah }\end{array}$ & $\begin{array}{c}\text { Rata-rata } \\
\text { tahun } \\
\text { bersekolah }\end{array}$ & $\begin{array}{c}\text { GNI per } \\
\text { Kapita } \\
\text { (PPP USD) }\end{array}$ \\
\hline Chile & 0,832 & 42 & 81,7 & 15,2 & 9,8 & 21.290 \\
$\begin{array}{c}\text { Peru } \\
\text { Argentina }\end{array}$ & 0,734 & 84 & 74,6 & 13,1 & 9,0 & 11.015 \\
$\begin{array}{c}\text { Latin } \\
\text { Amerika }\end{array}$ & 0,836 & 40 & 76,3 & 17,9 & 9,8 & 22.050 \\
$\begin{array}{c}\text { dan } \\
\text { Karibian }\end{array}$ & 0,748 & - & 75,0 & 14,0 & 8,2 & 14.242 \\
HDI tinggi & 0,896 & - & 80,5 & 16,4 & 11,8 & 41.584 \\
\hline
\end{tabular}

Sumber: Human Development Report (2015) 
Tabel 3

Nilai Tambah per sektor (dalam juta USD dan \% GDP) Chile dari tahun 2011 - 2015

\begin{tabular}{|c|c|c|c|c|c|c|c|c|c|c|}
\hline \multirow{2}{*}{$\begin{array}{c}\text { Nilai } \\
\text { Tambah } \\
\text { Sektor }\end{array}$} & \multicolumn{2}{|c|}{2011} & \multicolumn{2}{|c|}{2012} & \multicolumn{2}{|c|}{2013} & \multicolumn{2}{|c|}{2014} & \multicolumn{2}{|c|}{2015} \\
\hline & USD & \%GDP & USD & \%GDP & USD & $P$ & USD & \%GDP & USD & \%GDP \\
\hline Pertanian & 8.247 & 3.583 & 7.791 & 3.213 & 8.364 & 3.301 & 8.825 & 3.732 & 8.516 & 3.887 \\
\hline Industri & 89.116 & 38.719 & 88.849 & 36.639 & 88.603 & 34.965 & 81.783 & 34.582 & 72.021 & 32.874 \\
\hline Manufaktur & 27.489 & 11.943 & 28.656 & 11.817 & 30.049 & 11.858 & 27.594 & 11.668 & 26.168 & 11.944 \\
\hline Jasa & 132.797 & 57.698 & 145.859 & 60.148 & 156.439 & 61.734 & 145.883 & 61.686 & 138.548 & 63.240 \\
\hline
\end{tabular}

Sumber: diolah dari worldbank.org (2016)

Berdasarkan data dari worldbank GDP dikisaran -1,4\% (konsumsi barang (2016) pada gambar 3, ketergantungan impor lebih banyak pada tahun 2013) hingga Pemerintahan Chile terhadap bantuan lebih 1,2\% (surplus pendapatan dari ekspor di kecil dibandingkan negara-negara di Amerika tahun 2014). Total nilai ekspor-impor Chile Latin, kecuali Argentina, dan negara-negara dari tahun 2011 hingga 2015 dapat dilihat di Karibia. Chile juga masih sedikit pada gambar 5. Pada produk jasa, bergantung pada Impor berdasarkan data berdasarkan data intracen (2016) pada dari Intracen (2016) pada gambar 4, dimana gambar 6, Chile masih mengandalkan berdasarkan data dari tahun 2011 - 2015 importasi jasa.

terlihat perbedaan impor-ekspor terhadap \%

Gambar 3

Ketergantungan Terhadap Bantuan (Official Development Assistance/Gross National Income) Chile dengan beberapa negara sekitar

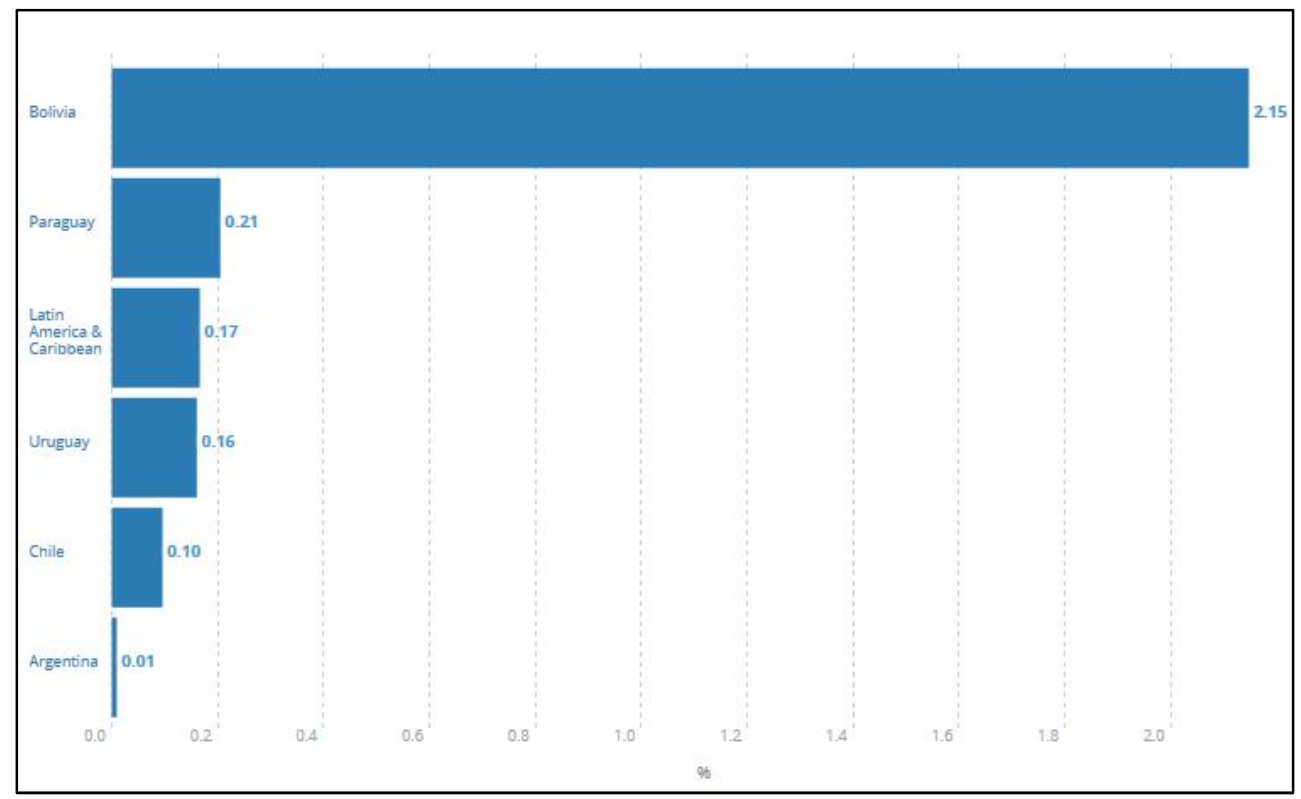

Sumber: diolah dari worldbank.org (2016) 
Gambar 4

Perkembangan Ekspor - Impor Produk Barang di Chile

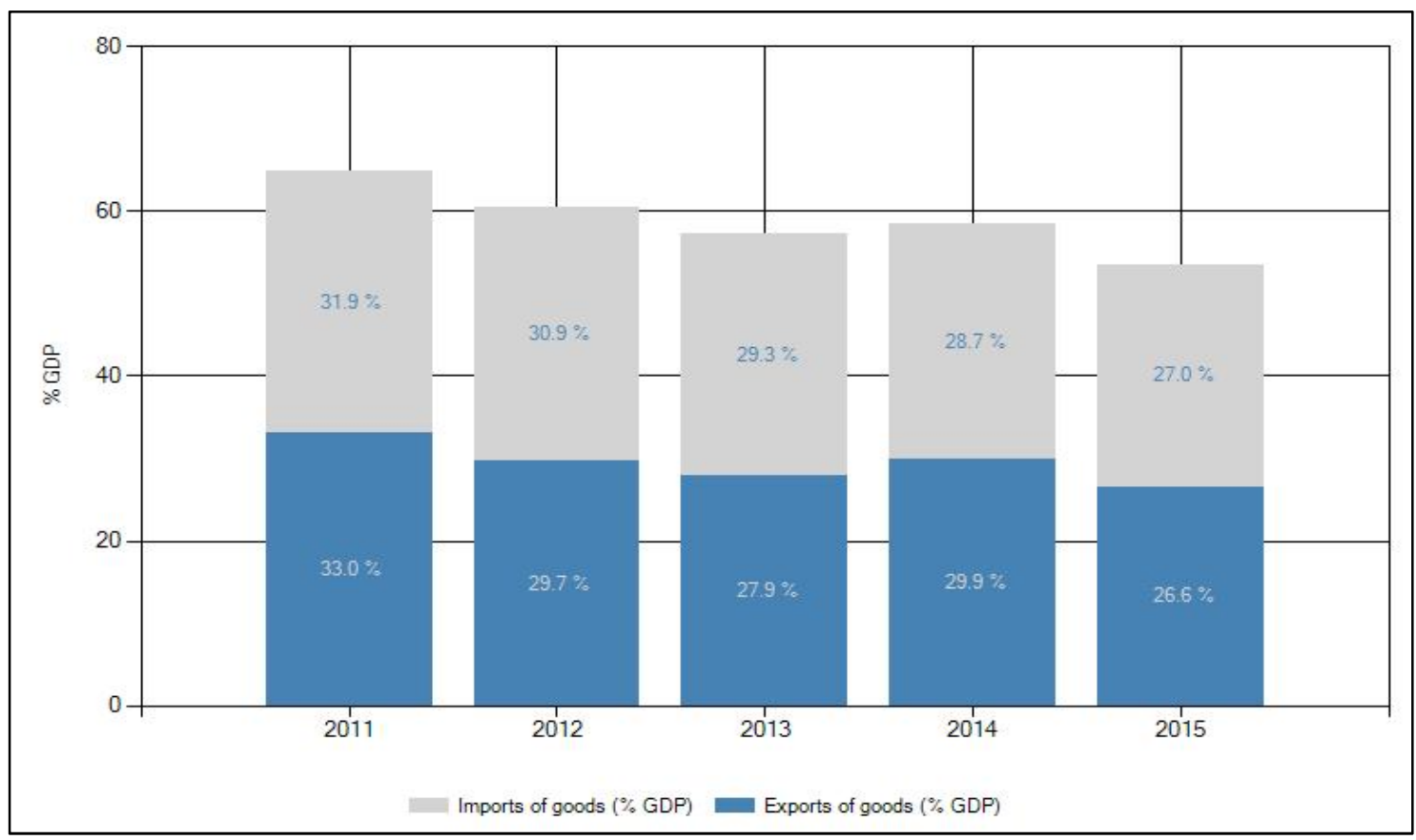

Sumber: intracen.org (2016)

Gambar 5

Total Ekspor - Impor Produk barang di Chile

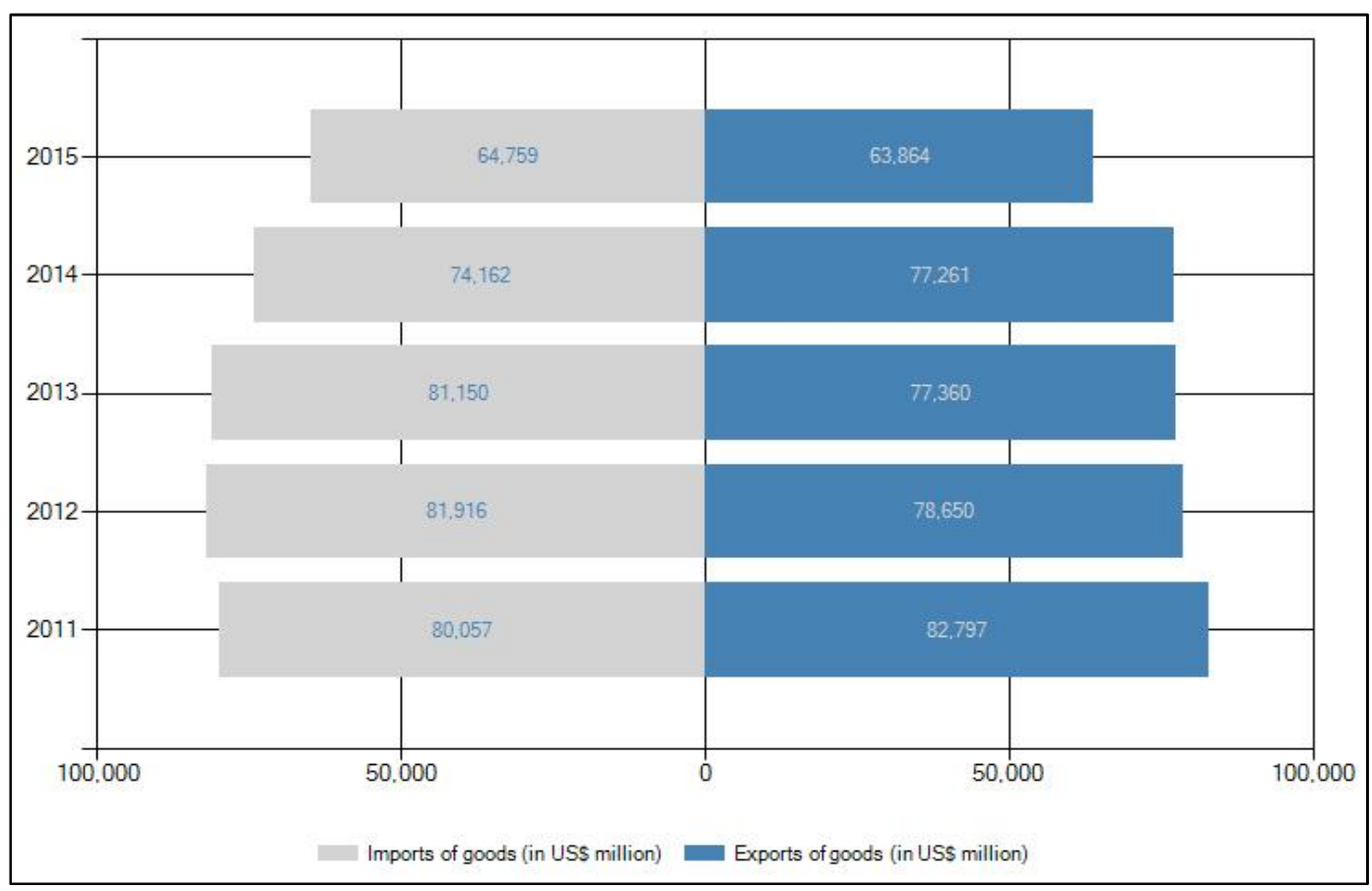

Sumber: intracen.org (2016) 


\section{Gambar 6}

\section{Perkembangan Ekspor - Impor Produk Jasa di Chile}

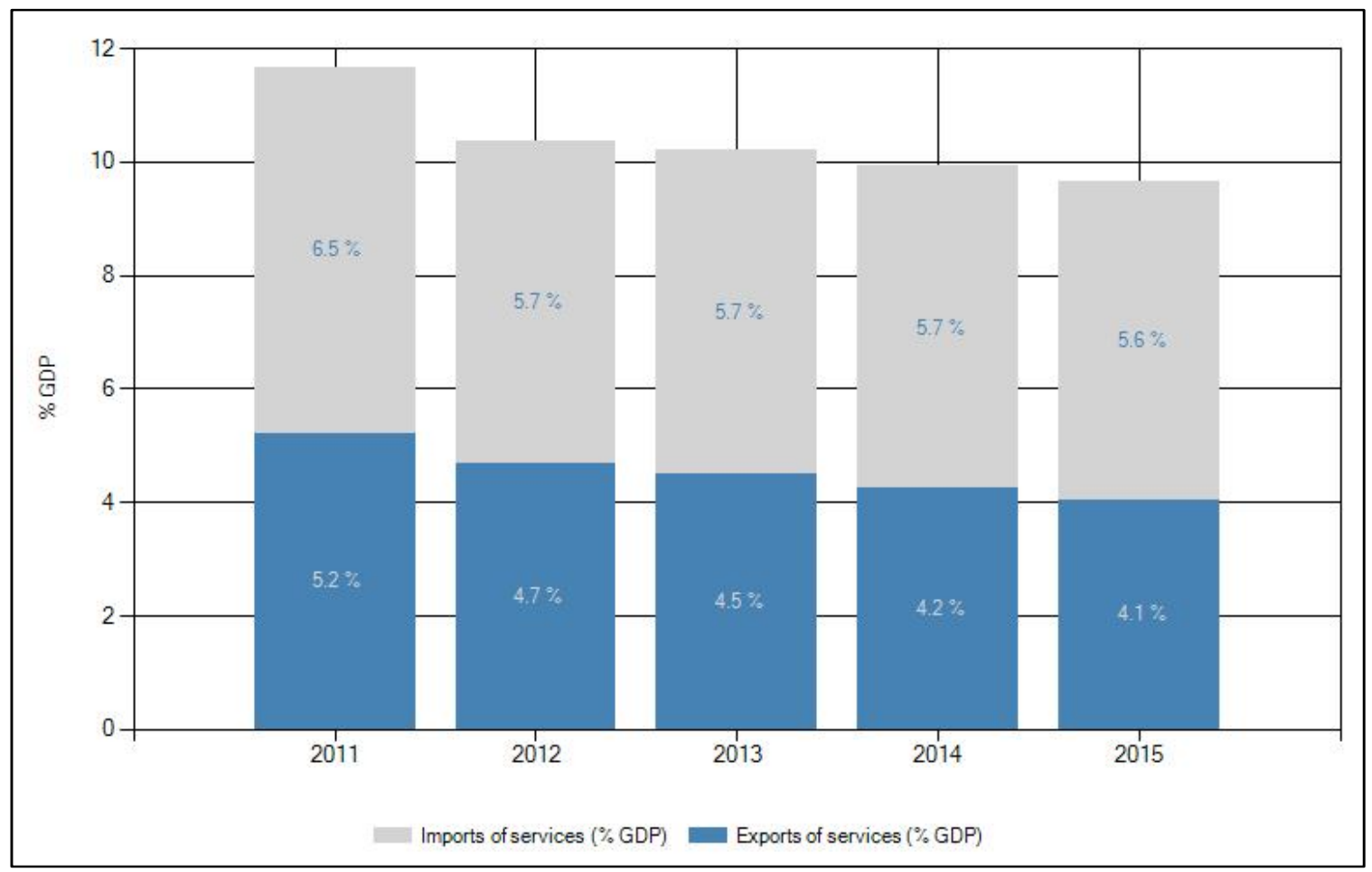

Sumber: intracen.org (2016)

\section{KERJASAMA PERDAGANGAN CHILE DENGAN BEBERAPA NEGARA}

Chile telah melakukan kerjasama dagang dengan beberapa negara di dunia, diantaranya dengan Kanada (Canada-Chile Free Trade Agreement) pada 5 Juli 1997, Singapura (Trans-Pasific Strategic Economy Partnership Agreement) pada 18 Juli 2005 dan Vietnam (Chile-Vietnam Free Trade Agreement) pada 4 Februari 2014.

\section{Kerjasama Chile dengan Canada}

Berdasarkan data dari Office of the Chief Economist, Foreign Affairs and International Trade Canada (2013), kondisi makroekonomi Kanada sejak implementasi (CCFTA) pada tahun 1997, nilai perdagangan ekspor Kanada ke Chile meningkat lebih dari dua kalinya, meningkat dari sebelumnya USD 392 juta pada tahun 1997 ke angka USD 819 juta pada tahun 2011 (gambar 7). Lebih dari 15 tahun sejak kerjasama dimulai, nilai ekspor Kanada ke Chile meningkat 5,4\% setiap tahunnya, mengalahkan ekspor ke negara Amerika Latin lainnya seperti Argentina dan Brazil, dimana Kanada tidak memiliki perjanjian kerjasama khusus perdagangan. Pada periode yang sama, ekspor dagangan Kanada ke seluruh wilayah Amerika Latin juga meningkat 5,4\%. Akibatnya, Chile menjadi negara ketiga di Amerika Latin, setelah Meksiko dan Brazil pada tahun 2011 dimana sebelumnya, Chile hanya masuk tujuh besar tujuan ekspor perdagangan Kanada di daerah tersebut (tabel 4). 
Gambar 7

Nilai Perdagangan Kanada dengan Chile (dalam juta USD)

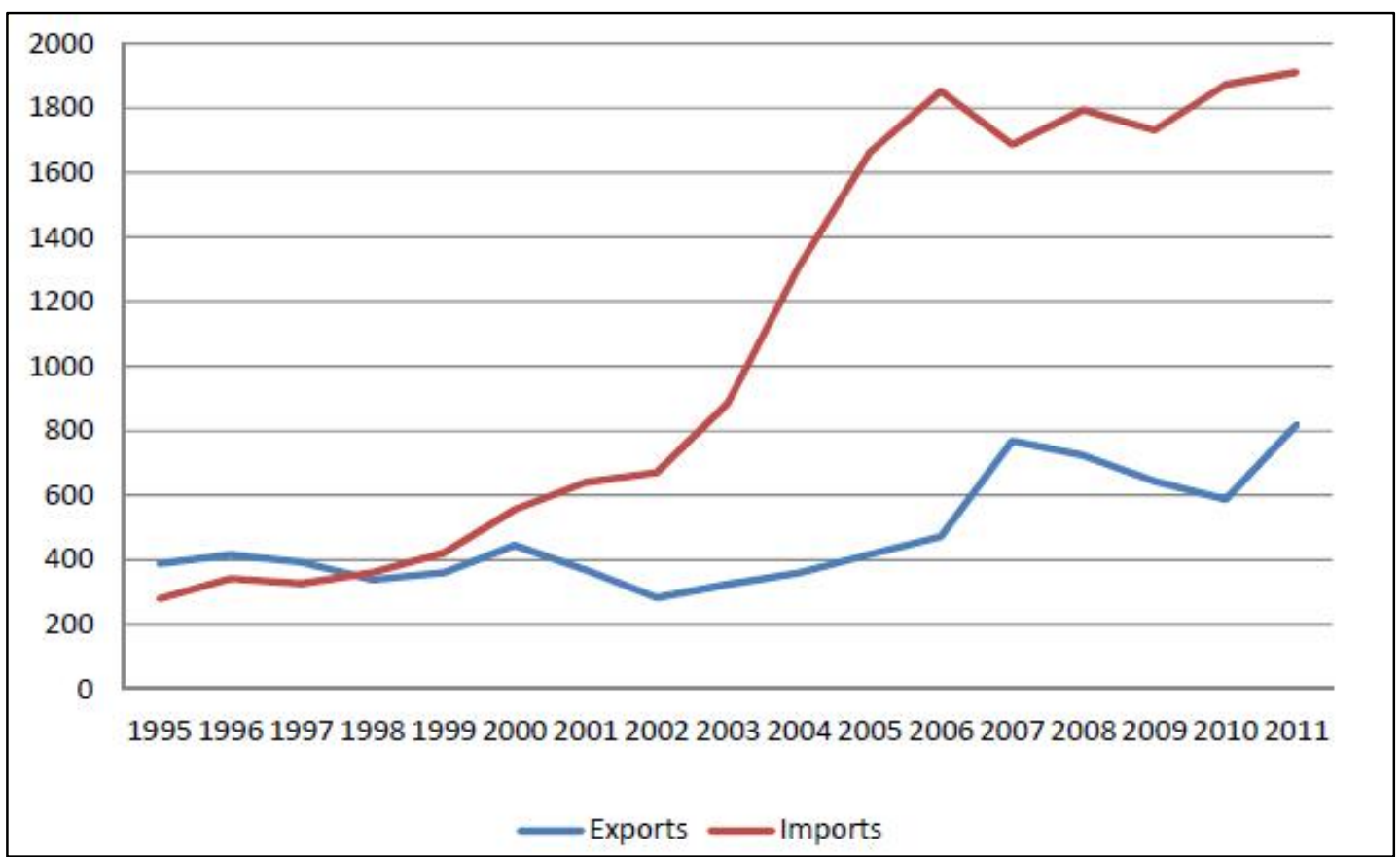

Sumber: Office of the Chief Economist, Foreign Affairs and International Trade Canada (2013)

Tabel 4

Nilai Perdagangan Kanada Dengan Negara Utama di Amerika Latin Tahun 1997 hingga 2011, dalam juta USD

\begin{tabular}{lcccccc}
\hline & \multicolumn{3}{c}{ Ekspor } & \multicolumn{3}{c}{ Impor } \\
\cline { 2 - 7 } & $\mathbf{1 9 9 7}$ & $\mathbf{2 0 1 1}$ & $\begin{array}{c}\text { Pertumbuhan } \\
\mathbf{( \% )}\end{array}$ & $\mathbf{1 9 9 7}$ & $\mathbf{2 0 1 1}$ & $\begin{array}{c}\text { Pertumbuhan } \\
\text { (\%) }\end{array}$ \\
\hline Argentina & 409 & 495 & 1,4 & 233 & 2.359 & 18,0 \\
Brazil & 1.693 & 2,841 & 3,8 & 1.320 & 3.880 & 8,0 \\
Chile & 392 & 819 & 5,4 & 326 & 1.911 & 13,5 \\
Kolombia & 473 & 761 & 3,5 & 314 & 800 & 6,9 \\
Peru & 312 & 516 & 3,7 & 135 & 4.403 & 28,3 \\
Venezuela & 953 & 607 & $-3,2$ & 972 & 739 & $-1,9$ \\
Meksiko & 1.277 & 5.476 & 11,0 & 7.022 & 24.573 & 9,4 \\
Amerika & & & & & \\
Latin dan & 6.790 & 14.131 & 5,4 & 12.060 & 43.106 & 9,5 \\
Karibia & 298.069 & 447.501 & 2,9 & 272.946 & 445.992 & 3,6 \\
Dunia & \multicolumn{7}{c}{ Sumber: Office of the Chief Economist, Foreign Affairs and International Trade Canada (2013) }
\end{tabular}


Nilai impor produk Kanada dari Chile juga terjadi peningkatan yang signifikan. Nilai total impor meningkat enam kali lipat dari sebelumnya USD 326 juta di tahun 1997 menjadi USD 1,9 miliyar di tahun 2011. Nilai ini setara dengan $13,5 \%$ per tahunnya, dan jika dibandingkan dengan pertumbuhan untuk nilai yang berasal dari seluruh negara Amerika Latin lainnya yang hanya sekitar $9,5 \%$.

Nilai impor perdagangan Kanada meningkat lebih cepat dari tahun 1996 hingga 2011. Pada gambar 8 terlihat nilai impor dari sektor yang mengalami pemotongan tarif lebih dari 10 persen bertumbuh 1.190 persen, dibandingkan sektor dengan pengurangan tarif 5,1 - 10 persen. Nilai impor dengan pemotongan kurang dari lima persen mengalami penurunan 36 persen pada periode yang sama. Sedangkan nilai perdagangan impor Kanada yang dibebaskan tarifnya mengalami peningkatan hingga 750 persen pada periode yang sama.

\section{Gambar 8}

Pertumbuhan Nilai Impor Kanada dari Chile dengan Berlakunya Pengurangan Tarif CCFTA (\%), $1996-2011$

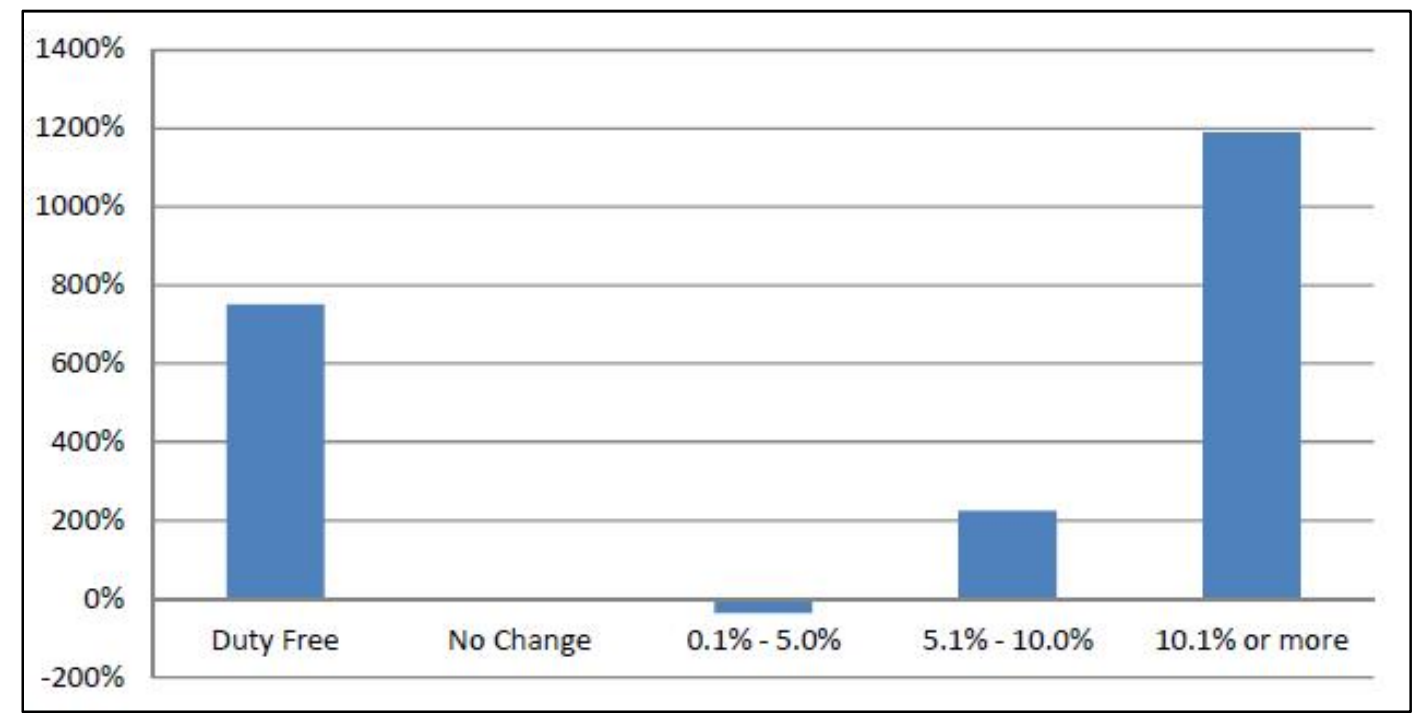

Sumber: Office of the Chief Economist, Foreign Affairs and International Trade Canada (2013)

Nilai impor perdagangan Chile dari Kanada terjadi peningkatan yang tidak signifikan pada rentang waktu 1996 hingga 2011. Pada gambar 9 terlihat nilai impor Chile untuk barang dari Kanada meningkat 189 persen untuk sektor yang menerapkan pengurangan tarif lebih dari 10 persen. Hal ini kontras dengan sektor yang pengurangan tarifnya dibawah 10 persen dimana tidak terjadi pertumbuhan. Sedangkan untuk sektor yang dibebaskan tarifnya mengalami peningkatan kuat hingga lebih dari 500 persen.

Tabel 5 melaporkan pertumbuhan impor Kanada dengan barang yang berasal dari Amerika Latin saat diberlakukannya pengurangan tarif saat diberlakukannya CCFTA. Pertumbuhan terbesar terjadi pada sektor yang dibebaskan tarifnya, sedangkan pada sektor tanpa pengurangan tarif cenderung tidak terjadi pertumbuhan impor di Kanada. 
Tren pertumbuhan ekspor (tabel 6) negara tanpa FTA. Namun, pilihan untuk yang sama terjadi pada ekspor Kanada ke negara-negara referensi menjadi terbatas Chile jika dibandingkan dengan ekspor ke karena banyaknya mitra FTA dari Chile.

\section{Gambar 9}

Pertumbuhan Nilai Impor Chile dari Kanada dengan Berlakunya Pengurangan Tarif CCFTA (\%), $1996-2011$

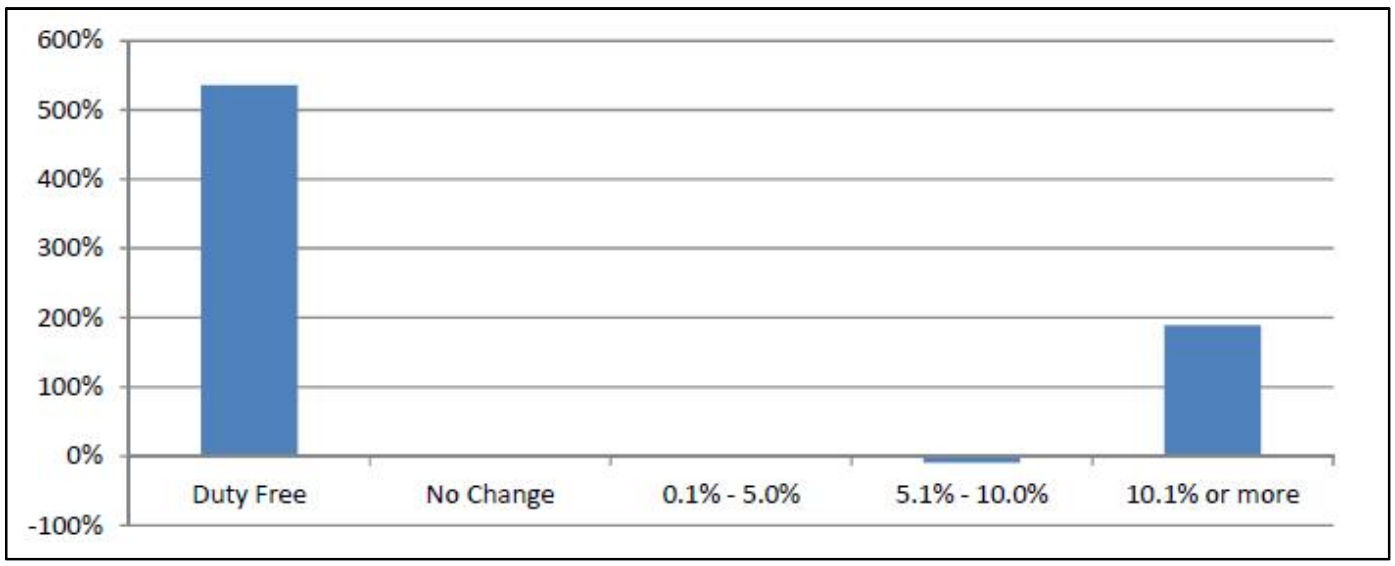

Sumber: Office of the Chief Economist, Foreign Affairs and International Trade Canada (2013)

Ekonomi Cile, menurut majalah Finance and Development, IMF (2000), mengalami penurunan yang signifikan pada akhir tahun 1990an dan awal 2000-an disebabkan oleh krisis keuangan Asia pada awal tahun 1997, dan tetap lamban hingga tahun 2003. Nilai impor Chile dari dunia menurun tajam antara tahun 1996 dan 2003. Selama periode ini, nilai impor barang dagangan dari Kanada total turun sebesar 18,5 persen dan dari AS turun tajam 32,7 persen. Di kelima kategori produk yang dikategorikan tingkat pengurangan tarif di bawah CCFTA itu, empat kategori dilaporkan turun signifikan dalam nilai impor untuk produk yang berasal dari AS dibandingkan dari Kanada. Produk dengan penurunan tarif lebih dari 10 persen mengalami penurunan yang paling signifikan dalam nilai impor dari AS, sementara pada periode yang sama nilai impor dari Kanada terjadi pertumbuhan. Pola data yang disajikan dalam Tabel 4 menunjukkan betapa kuatnya CCFTA membantu mengurangi kerugian ekspor Kanada di pasar Chili selama krisis ekonomi di Chile.

Perbandingan antara Kanada dan Australia menyajikan gambaran yang sama sekali berbeda. Dari tahun 1996 sampai 2008, Chili telah meningkat impor dari Australia dalam dua kategori produk sedangkan nilai impor dari Kanada hanya meningkat pada produk dengan penurunan tarif lebih dari 10 persen berdasarkan tabel 6. Menurut laporan Office of Chief Economist (2013), Kanada dan Australia memiliki banyak persamaan karakteristik ekonomi, misalnya, keduanya adalah eksportir utama komoditas, akan tetapi komposisi ekspor mereka sangat berbeda. Ekspor Australia ke Chile terkonsentrasi di dua kategori produk yaitu produk dari batubara dan batubara serta daging sapi. Sementara ekspor Kanada ke Chile yang lebih beragam, mulai dari batubara, gandum, produk mineral, dan minyak biji hingga mesin dan peralatan. Hal ini membuat perbandingan secara langsung 
terhadap keduanya akan sulit. Misalnya, dalam kategori produk dengan penurunan tarif lebih dari 10 persen, nilai impor Chile dari Kanada meningkat hingga 106.5 persen, namun Australia tidak mengekspor produk yang sama seperti Kanada dalam kategori ini.
Di tingkat sektoral, nilai pertumbuhan ekspor Kanada ke Cile terkonsentrasi di dua kategori produk yaitu produk dengan penurunan tarif lebih dari 10 persen dan produk yang sudah memiliki tugas akses bebas ke pasar Chili sebelum pelaksanaan CCFTA.

Tabel 5

Pertumbuhan Nilai Perdagangan Kanada Dengan Negara Amerika Latin saat Berlakunya CCFTA, 1996-2011

\begin{tabular}{llr}
\hline Kategori Pengurangan Tarif dalam Skema CCFTA & Negara & Pertumbuhan Impor \\
\hline & Chile & 748,9 \\
Bebas Pajak & Argentina & $3.567,8$ \\
& Brazil & 438,1 \\
& Kolombia & 235,4 \\
& Meksiko & 431,8 \\
& Peru & $6.972,3$ \\
& Venezuela & 733,5 \\
\hline \multirow{2}{*}{ Tanpa Perubahan Tarif } & Chile & 0,0 \\
& Argentina & 94,0 \\
& Brazil & $-21,2$ \\
& Kolombia & 388,5 \\
& Meksiko & 0,0 \\
& Peru & 0,0 \\
& Venezuela & $-98,2$ \\
\hline $0,1-5$ persen nilai & Chile & $-36,2$ \\
& Argentina & 324,4 \\
& Brazil & 265,3 \\
& Kolombia & 511,2 \\
& Meksiko & 491,1 \\
& Peru & 46,5 \\
& Venezuela & $-36,6$ \\
\hline & Chile & 224,5 \\
& Argentina & 759,0 \\
& Brazil & 489,3 \\
& Kolombia & 115,4 \\
& Meksiko & 536,1 \\
& Peru & 937,8 \\
& Venezuela & 208,4 \\
\hline
\end{tabular}




\begin{tabular}{llr}
\hline Kategori Pengurangan Tarif dalam Skema CCFTA & Negara & Pertumbuhan Impor \\
\hline & Chile & $1.189,9$ \\
& Argentina & 231,7 \\
10,1 persen nilai atau lebih & Brazil & 474,9 \\
& Kolombia & 6,6 \\
& Meksiko & 328,1 \\
& Peru & 496,8 \\
& Venezuela & $-95,3$ \\
\hline
\end{tabular}

Sumber: Office of the Chief Economist, Foreign Affairs and International Trade Canada (2013)

Tabel 6

Pertumbuhan Nilai Perdagangan Impor Chile dari Kanada, Australia dan Amerika Serikat saat Berlakunya pengurangan tarif CCFTA, 1996-2003 dan 1996-2008

\begin{tabular}{|c|c|c|c|c|}
\hline $\begin{array}{l}\text { Kategori } \\
\text { Pengurangan } \\
\text { Tarif dibawah } \\
\text { CCFTA }\end{array}$ & \multicolumn{2}{|c|}{$\begin{array}{l}\text { Pertumbuhan Nilai Impor Chile dari } \\
\text { Kanada dan Australia } \\
(\%, 1996-2008)\end{array}$} & \multicolumn{2}{|c|}{$\begin{array}{l}\text { Pertumbuhan Nilai Impor Chile dari } \\
\text { Kanada dan Amerika Serikat (\%, } \\
\text { 1996-2003) }\end{array}$} \\
\hline \multirow{2}{*}{ Bebas Pajak } & Kanada & 0,0 & Kanada & 0,0 \\
\hline & Australia & $6.413,5$ & Amerika Serikat & $-70,6$ \\
\hline \multirow{2}{*}{$\begin{array}{l}\text { Tanpa Perubahan } \\
\text { Tarif }\end{array}$} & Kanada & 0,0 & Kanada & 0,0 \\
\hline & Australia & 0,0 & Amerika Serikat & $-10,7$ \\
\hline \multirow{2}{*}{$0,1-5$ persen nilai } & Kanada & 0,0 & Kanada & 0,0 \\
\hline & Australia & 102,7 & Amerika Serikat & $-32,5$ \\
\hline \multirow{2}{*}{$\begin{array}{l}5,1 \text { - } 10 \text { Persen } \\
\text { nilai }\end{array}$} & Kanada & $-41,9$ & Kanada & $-89,7$ \\
\hline & Australia & 0,0 & Amerika Serikat & 0,0 \\
\hline \multirow{2}{*}{$\begin{array}{l}\text { 10,1 persen nilai } \\
\text { atau lebih }\end{array}$} & Kanada & 106,5 & Kanada & 6,6 \\
\hline & Australia & 0,0 & Amerika Serikat & $-84,7$ \\
\hline
\end{tabular}

Sumber: Office of the Chief Economist, Foreign Affairs and International Trade Canada (2013)

\section{Kerjasama Chile dengan Singapura}

Kerjasama Singapura dengan Chile mulai dilakukan pada tahun 2005 dalam skema Trans-Pasific Strategic Economy Partnership Agreement (TPP) bersama dengan Brunei Darussalam dan Selandia Baru biasa disebut P4. Tujuan dari dari perjanjian ini menurut Kawai (2010) adalah untuk mengurangi 90 persen tarif masuk diantara negara anggota dan mengurangi semua tarif hingga nol pada tahun 2015. Perjanjian TPP bersifat komprehensif yang mencakup banyak unsur tambahan dari WTO termasuk ROO (Rules of Origin), perbaikan perdagangan, ukuran aturan terkait sanitary dan phytosanitary, hambatan teknis perdagangan, kekayaan intelektual, pengadaan pemerintah dan kebijakan persaingan. Sebagai bagian dari kesimpulan dari negosiasi, negara-negara P4 setuju untuk bernegosiasi pada permasalahan jasa keuangan dan investasi dalam waktu dua tahun sejak TPP ini berlaku. Pada tahun 2016, keanggotaan TPP telah bertambah 
dengan masuknya Australia, Kanada, Jepang, Malaysia, Meksiko, Peru, Amerika Serikat dan Vietnam. Berdasarkan data perdagangan dari trademap (2016) pada tabel 7 terlihat pertumbuhan berdasarkan data dari tahun 2011 hingga 2015 dimana terjadi pertumbuhan nilai perdagangan pada produk yang menerima nol persen tarif masuk ke Chile.

\section{Kerjasama Chile dengan Vietnam}

Vietnam, berdasarkan data Online (2016) mengenai Asia Regional Integration Center, menandatangani perjanjian TPP dimana didalamnya terdapat Chile pada 4 Februari 2016. Kerjasama Vietnam dengan Chile belum dapat dirasakan karena masih baru dan belum berpengaruh terhadap perekonomian Vietnam. Akan tetapi, berdasarkan data perdagangan dari trademap (2016) pada tabel 8 terlihat potensi pertumbuhan yang tinggi berdasarkan data dari tahun 2011 hingga 2015 dimana terjadi pertumbuhan nilai perdagangan pada produk yang menerima nol persen tarif masuk ke Chile. Potensi yang lebih tinggi lagi dapat terjadi pada produk yang masih memiliki tarif masuk diatas nol persen tetapi pertumbuhannya tetap tinggi, seperti produk dengan kode HS 58 pada tabel 8, meskipun tarif masuk yang diterapkan sebesar 2 persen, pertumbuhan ekspornya tetap tinggi hingga 120 persen. Begitu juga dengan produk dengan kode HS 73, dimana tarif yang dikenakan sebesar 4 persen, tetapi pertumbuhannya diangka 120 persen.

Tabel 7

Pertumbuhan Nilai Perdagangan ekspor Singapura ke Chile saat Berlakunya Tarif Nol Persen untuk Beberapa Produk Utama, 2011-2015

\begin{tabular}{|c|c|c|c|}
\hline \multirow[b]{2}{*}{$\begin{array}{c}\text { Kode } \\
\text { HS } \\
\text { Produk }\end{array}$} & \multirow[b]{2}{*}{ Deskripsi Produk } & \multicolumn{2}{|c|}{ Nilai Ekspor Singapura ke Chile } \\
\hline & & $\begin{array}{l}\text { Pertumbuhan per } \\
\text { tahun, 2011-2015, \% }\end{array}$ & $\begin{array}{r}\text { Tarif ad valorem } \\
\text { setara diterapkan } \\
\text { oleh Cile ke Singapura }\end{array}$ \\
\hline 70 & Kaca dan gelas & 205 & 0 \\
\hline 95 & $\begin{array}{l}\text { Mainan, game dan persyaratan } \\
\text { olahraga; bagian dan perlengkapannya }\end{array}$ & 121 & 0 \\
\hline 57 & $\begin{array}{l}\text { Karpet dan penutup lantai tekstil } \\
\text { lainnya }\end{array}$ & 103 & 0 \\
\hline 23 & $\begin{array}{l}\text { Residu dan limbah dari industri } \\
\text { makanan; siap pakan ternak }\end{array}$ & 99 & 0 \\
\hline 62 & $\begin{array}{l}\text { Artikel dari pakaian dan aksesori } \\
\text { pakaian, bukan rajutan atau kaitan }\end{array}$ & 70 & 0 \\
\hline
\end{tabular}

\section{SKEMA KERJASAMA PERDAGANGAN DALAM TPP DAN APEC}

TPP memiliki potensi untuk tumbuh dan menyertakan banyak negara lain berdasarkan klausul perjanjian aksesi. Menurut Kawai (2010) pada bulan September 2008, AS mengumumkan keinginannya untuk memasuki perundingan komprehensif agar dapat bergabung. Tak lama setelah itu, Australia dan Peru mengumumkan bahwa mereka akan bergabung dalam perundingan, begitu juga Malaysia dan VietNam. Dengan demikian, TPP bisa membantu memperluas dan memperkuat hubungan ekonomi dan strategis di antara sesama 
anggota APEC dan dapat meletakkan landasan yang lebih luas untuk Free Trade Area of the Asia-Pacific (FTAAP). APEC sendiri, menurut Williams (2013), memandang dirinya sebagai "inkubator" dari FTAAP dan salah satu tujuannya adalah mendukung TPP.

Menurut Hoang (2015), TPP menetapkan standar baru dalam perjanjian perdagangan di masa depan. Perjanjian ini bersifat komprehensif dan ambisius di semua area: kompetisi; kerjasama dan peningkatan kapasitas; menyediakan layanan lintas batas; bea cukai; e-dagang; lingkungan; jasa keuangan; pengadaan pemerintah; kekayaan intelektual; investasi; tenaga kerja; masalah hukum; akses pasar barang; ketentuan asal; sanitary dan phytosanitary (SPS); technical barriers to trade (TBT); telekomunikasi; pergerakan alami manusia; perbaikan perdagangan.

Tabel 8

Pertumbuhan Nilai Perdagangan ekspor Vietnam ke Chile tahun 2011-2015 untuk Beberapa Produk Utama

\begin{tabular}{|c|c|c|c|}
\hline \multirow[b]{2}{*}{$\begin{array}{l}\text { Kode } \\
\text { HS } \\
\text { Produk }\end{array}$} & \multirow[b]{2}{*}{ Deskripsi Produk } & \multicolumn{2}{|c|}{ Nilai Ekspor Vietnam ke Chile } \\
\hline & & $\begin{array}{l}\text { Pertumbuhan per } \\
\text { tahun, 2011-2015, \% }\end{array}$ & $\begin{array}{r}\text { Tarif ad valorem } \\
\text { setara diterapkan } \\
\text { oleh Cile ke Vietnam }\end{array}$ \\
\hline 71 & $\begin{array}{l}\text { Mutiara alam atau budidaya, batu mulia } \\
\text { atau semi mulia, logam mulia, logam } \\
\text { lapis }\end{array}$ & 356 & 0 \\
\hline 85 & $\begin{array}{l}\text { Mesin listrik dan peralatan dan } \\
\text { bagiannya; perekam suara dan alat } \\
\text { produksinya, televisi }\end{array}$ & 126 & 0 \\
\hline 12 & $\begin{array}{l}\text { Minyak biji dan buah-buahan } \\
\text { oleaginous; aneka biji, benih dan buah; } \\
\text { industri atau obat terkait }\end{array}$ & 86 & 0 \\
\hline 28 & $\begin{array}{l}\text { Bahan kimia anorganik; senyawa } \\
\text { organik atau anorganik dari logam } \\
\text { mulia, logam langka bumi }\end{array}$ & 61 & 0 \\
\hline 84 & $\begin{array}{l}\text { Mesin, peralatan mekanik, reaktor } \\
\text { nuklir, boiler; bagiannya }\end{array}$ & 105 & 1 \\
\hline 48 & $\begin{array}{l}\text { Kertas dan kertas karton; artikel pulp } \\
\text { kertas, kertas atau dari kertas karton }\end{array}$ & 95 & 1 \\
\hline 49 & $\begin{array}{l}\text { Buku cetak, surat kabar, gambar dan } \\
\text { produk lainnya dari industri } \\
\text { percetakan; manuskrip, dsb }\end{array}$ & 82 & 1 \\
\hline 58 & $\begin{array}{l}\text { Kain tenunan khusus; kain tekstil } \\
\text { berumbai; renda; permadani; hiasan; } \\
\text { sulaman }\end{array}$ & 120 & 2 \\
\hline 63 & $\begin{array}{l}\text { Barang tekstil buatan lainnya; set; } \\
\text { pakaian usang dan barang tekstil } \\
\text { terpakai; perca }\end{array}$ & 58 & 3 \\
\hline 73 & Artikel dari besi atau baja & 120 & 4 \\
\hline
\end{tabular}


Berdasarkan hasil penelitian terhadap penilaian kuantitatif mengenai integrasi TPP dan Asia - Pasifik oleh Petri (2011), perjalanan menuju terwujudnya FTAAP terlihat alurnya pada gambar 10. Skenario penelitiannya didasarkan dari Asian Track yang dibangun berdasarkan upaya integrasi Asia, termasuk rencana cetak biru ASEAN Economic Community dan perjanjian perdagangan bilateral dengan Tiongkok, Jepang dan Korea. Perjanjian ini meliputi cakupan perdagangan yang luas, tetapi melibatkan lebih sedikit perjanjian dan memungkinkan penerimaan yang lebih luas dibandingkan perjanjian perdagangan dari TPP Track.

\section{Gambar 10}

Skema Perjalanan Asia Track dan TPP Track

\begin{tabular}{|l|l|}
\hline 2012 & \multicolumn{2}{|c|}{2015} \\
\hline \multicolumn{1}{|c|}{ Asian track } & \\
\hline $\begin{array}{l}\text { CJK } \\
\text { China, Japan, Korea }\end{array}$ & $\begin{array}{l}\text { EAFTA } \\
\text { Consolidates ASEAN+3 }\end{array}$ \\
\hline Trans-Pacific track & FTAAP \\
\hline TPP9 & $\begin{array}{l}\text { TPP13 } \\
\text { Korea, Japan, Canada, } \\
\text { Moxico join) }\end{array}$ \\
\hline
\end{tabular}

Sumber: Petri (2011)

VIII. ANALISA PENGARUH KERJASAMA TPP TERHADAP PEREKONOMIAN DUNIA BERDASARKAN MODEL CGE

Petri (2016) mengembangkan hasil penelitian sebelumnya dan memperkirakan perubahan paduk pada Penghasilan Domestik Brutto (PDB) dengan adanya perjanjian TPP di Asia dan Dunia dalam rentang 2015 hingga 2030 menggunakan model analisis Computerable General Equilibrium (CGE) (Tabel 9 dan 10). Tabel 9 merupakan hasil perkiraan terbaru dari penilaian kuantitatif mengenai integrasi TPP dan Asia - Pasifik yang dilakukan Petri (2016) dimana hasil analisis yang diperoleh merupakan ukuran utama dari manfaat yang disebut "pendapatan pemasukan riil". Istilah ini mengacu pada definisi teknis yang kaku mengenai variasi persamaan, indikator yang sering digunakan ekonom untuk menilai perubahan kebijakan. Hal ini digunakan untuk mengukur berapa banyak penghasilan tambahan yang negara butuhkan, tanpa TPP, untuk melakukan pengeluaran nyata yang diinginkan sama dengan saat mengikuti TPP. Pengeluaran biasanya bergantung pada pendapatan yang diperoleh dari produksi, sehingga keuntungan pendapatan riil akan sama (tapi tidak identik) untuk keuntungan dalam PDB riil. Karena PDB nyata dan pendapatan riil keduanya disajikan dalam harga konstan, hubungan antara keduanya bergantung pada harga relatif. Misalnya, jika TPP menurunkan harga output relatif terhadap harga barang-barang konsumsi, maka peningkatan PDB yang diberikan akan sesuai dengan peningkatan pendapatan riil yang lebih kecil.

Petri (2016) memproyeksikan keuntungan terjadi pada negara Jepang, 
Malaysia, dan Vietnam. Jepang mendapatkan keuntungan dari peningkatan akses pasar di seluruh wilayah TPP, termasuk liberalisasi awal impor mobil di pasar selain dari Amerika Serikat, dan dari reformasi domestik yang dilakukan untuk mengurangi distorsi dalam layanan dan sektor investasi yang diproteksi sebelumnya oleh negara anggota TPP. Presentase keuntungan yang sangat besar diraih Vietnam dan Malaysia, di mana perjanjian tersebut juga harus merangsang terjadinya reformasi di negara mereka dan tersedianya akses ke pasar luar negeri yang sebelumnya dilindungi. Presentase keuntungan yang signifikan lainnya diproyeksikan untuk perekonomian negara Brunei, Peru, Singapura, dan Selandia Baru.

Secara umum, TPP diperkirakan tidak memiliki efek besar pada pendapatan negara nonanggota. Penurunan kebanyakan disebabkan karena anggota TPP mengalihkan perdagangannya dari sebelumnya ke negara bukan anggota ke negara anggota akibat berkurangnya preferensi di pasar TPP. Kerugian dapat terjadi pada negara Tiongkok, India, dan Thailand, yang bersaing dengan anggota TPP untuk pasar mendapatkan pasar TPP. Untuk negara Korea Selatan, TPP akan mengikis keuntungan yang diperolehnya di pasar AS di bawah perjanjian KORUS. Terkecuali negara Thailand, kerugian ini lebih kecil dibandingkan dengan PDB. Beberapa negara nonanggota, termasuk Uni Eropa dan Hong Kong, akan mengalami peningkatan keuntungan bersih, sebagian karena asumsi bahwa ketentuan TPP meliberalisasi beberapa perdagangan dengan negara bukan anggota.

Tabel 9 menunjukkan pengaruh dari TPP pada perdagangan dan investasi asing langsung di tahun 2030. Nilai ekspor tahunan Amerika Serikat meningkat USD 357 Milyar atau 9,1 persen dan untuk semua negara TPP total keseluruhan USD 1.025 miliar atau 11,5 persen. Pola kenaikan ekspor mirip dengan kenaikan pendapatan; Amerika Serikat, Jepang, Vietnam, dan Malaysia memimpin pada tabel, dimana ekspor Jepang, Vietnam, dan Malaysia masing-masing tumbuh sebesar 20 persen atau lebih. Pengaruh pada nonanggota bervariasi; beberapa mendapatkan keuntungan dari ekspor dan lainnya mengalami kerugian. Karena efek impor serupa dengan efek ekspor berdasarkan asumsi neraca perdagangan yang normal, oleh karenanya nilai tersebut tidak dilaporkan.

Investasi masuk ke semua negara TPP meningkat USD 446 milyar atau 3,5 persen selama paduk 2030 dan investasi keluar sebesar USD 305 milyar atau 2 persen. Perubahan ini sebagian disebabkan oleh pertumbuhan PDB di berbagai daerah dan sebagian terjadi karena adanya pengurangan hambatan investasi. Para penerima terbesar dari investasi luar yang masuk dalam TPP adalah Amerika Serikat, Kanada, Jepang, dan Malaysia, sedangkan sumber terbesar yang melakukan investasi keluar adalah Amerika Serikat, Jepang, dan Uni Eropa. Negara TPP menarik lebih banyak investasi masuk (USD 446 milyar) daripada mereka menghabiskan untuk melakukan investasi keluar (USD 305 milyar). Hal ini mencerminkan penghasilan bersih yang dihasilkan dari investasi akibat meningkatnya perbaikan iklim berinvestasi.

\section{ANALISA PENGARUH KERJASAMA TPP BERDASARKAN SKEMA FTA INDONESIA}

Berbeda dengan pendapat Deardorff (2013) dimana TPP tidak akan berpengaruh besar terhadap perekonomian negara nonTPP dikarenakan:

1) Banyak dari negara-negara Asia di luar TPP sudah menjadi anggota atau memiliki perjanjian FTA dengan negara-negara TPP. Ekspor mereka ke negara-negara 
anggota sudah menerapkan tarif nol persen, sehingga dan karena itu tidak terjadi pengalihan perdagangan maupun penciptaan pasar baru perdagangan dapat terjadi.

2) Banyak dari negara-negara anggota TPP, termasuk negara Asia anggota AFTA, sudah menjadi anggota dari FTA dengan individu anggota TPP. Ekspor dan impor mereka ke anggota FTA sudah menerapkan tarif nol persen, sehingga dan karena itu tidak terjadi pengalihan perdagangan maupun penciptaan pasar baru perdagangan dapat terjadi.

Saat ini, menurut Asia Regional Integration Center (2016), Indonesia memiliki 17 FTA, 7 dalam tahapan negosiasi dan 10 sudah berjalan. Negara-negara yang terlibat di 10 FTA yang sudah berjalan tersebut:

a. Preferential Tariff Arrangement - Group of Eight Developing Countries, dengan melibatkan negara Bangladesh, Malaysia, Pakistan, Mesir, Iran, Nigeria dan Turki;

b. Pakistan - Indonesia Free Trade Agreement;

c. Japan - Indonesia Economic Partnership Agreement;

d. ASEAN Free Trade Area, dengan melibatkan negara Brunei Darussalam, Kambodia, Laos, Malaysia, Myanmar, Filipina, Singapura, Thailand dan Vietnam;

e. ASEAN - (Republic of) Korea Comprehensive Economic Cooperation Agreement;

f. ASEAN-People's Republic of China Comprehensive Economic Cooperation Agreement;

g. ASEAN-Japan Comprehensive Economic Partnership;

h. ASEAN-India Comprehensive Economic Cooperation Agreement; i. ASEAN-Australia and New Zealand Free Trade Agreement;

j. Trade Preferential System of the Organization of the Islamic Conference dengan melibatkan negara Bahrain, Mesir, Jordan, Kuwait, Lebanon, Maroko, Nigeria, Pakistan, Arab Saudi, Turki, Uganda, Bangladesh, Pantai Gading, Guinea, Iran, Islamic Republic of Maldives, Oman, Qatar, Senegal, Republik Arab Suriah, Tunisia, Uni Emirat Arab, Benin, Burkina Faso, Kamerun, Chad, Comoros, Djibouti, Gabon, Gambia, Guinea-Bissau, Irak, Libya, Malaysia, Mauritania, Niger, Palestina, Sierra Leone, Somalia dan Sudan

Tujuh FTA yang dalam taraf negosiasi adalah:

a. ASEAN-Hong Kong, China Free Trade Agreement,

b. India-Indonesia Comprehensive Economic Cooperation Arrangement

c. Indonesia-Australia Comprehensive Economic Partnership Agreement,

d. Indonesia-Chile Free Trade Agreement,

e. Indonesia-European Free Trade

Association Free Trade Agreement, melibatkan negara Islandia, Liechtenstein, Norwegia dan Swiss; Regional Comprehensive Economic Partnership, melibatkan negara anggota ASEAN, Australia, India, Jepang, Tiongkok, Republik Korea dan Selandia Baru

f. (Republic of) Korea-Indonesia Free Trade Agreement

Jika kita amati, negara-negara yang terlibat dalam 10 FTA yang sudah berjalan berkontribusi besar dalam perdagangan ekspor migas dan non migas Indonesia (tabel 1). Sedangkan wilayah Amerika berkontribusi besar dalam hal ekspor non migas. 
Tabel 9

Efek Pendapatan Riil dari TPP

\begin{tabular}{|c|c|c|c|c|c|c|c|}
\hline & \multicolumn{4}{|c|}{ Paduk (dalam Juta Dollar 2015) } & \multicolumn{3}{|c|}{$\begin{array}{l}\text { Perubahan dengan TPP } \\
\text { (dalam Juta Dollar 2015) }\end{array}$} \\
\hline & 2015 & 2020 & 2025 & 2030 & 2020 & 2025 & 2030 \\
\hline Anggota TPP & 28.969 & 32.971 & 37.094 & 41.011 & 98 & 291 & 465 \\
\hline Amerika Serikat & 18.154 & 20.736 & 23.372 & 25.754 & 29 & 88 & 131 \\
\hline Jepang & 4.214 & 4.462 & 4.693 & 4.924 & 39 & 91 & 125 \\
\hline Kanada & 1.981 & 2.227 & 2.472 & 2.717 & 8 & 22 & 37 \\
\hline Australia & 1.704 & 1.986 & 2.292 & 2.590 & 1 & 8 & 15 \\
\hline Meksiko & 1.339 & 1.598 & 1.868 & 2.169 & 3 & 11 & 22 \\
\hline Malaysia & 349 & 444 & 553 & 675 & 7 & 28 & 52 \\
\hline Singapura & 320 & 380 & 437 & 485 & 2 & 8 & 19 \\
\hline Chile & 269 & 329 & 397 & 463 & 0 & 2 & 4 \\
\hline Vietnam & 209 & 281 & 378 & 497 & 7 & 22 & 41 \\
\hline Peru & 219 & 287 & 363 & 442 & 1 & 6 & 11 \\
\hline Selandia Baru & 192 & 217 & 241 & 264 & 1 & 4 & 6 \\
\hline Brunei & 20 & 24 & 27 & 31 & 0 & 1 & 2 \\
\hline $\begin{array}{c}\text { Non Anggota- } \\
\text { TPP }\end{array}$ & 52.066 & 63.652 & 77.596 & 92.790 & 13 & 28 & 27 \\
\hline Eropa & 17.893 & 19.746 & 21.451 & 23.189 & 12 & 34 & 48 \\
\hline Tiongkok & 11.499 & 16.058 & 21.689 & 27.839 & -1 & -8 & -18 \\
\hline India & 2.210 & 3.086 & 4.197 & 5.487 & 0 & -2 & -5 \\
\hline Korea Selatan & 1.384 & 1.672 & 1.967 & 2.243 & -1 & -5 & -8 \\
\hline Indonesia & 927 & 1.240 & 1.687 & 2.192 & 0 & -1 & -2 \\
\hline Taiwan & 511 & 619 & 707 & 776 & 0 & 1 & 1 \\
\hline Thailand & 411 & 516 & 656 & 812 & -1 & -4 & -7 \\
\hline Filipina & 329 & 436 & 547 & 680 & 0 & -1 & -1 \\
\hline Hong kong & 300 & 358 & 412 & 461 & 2 & 4 & 6 \\
\hline Dunia & 81.035 & 96.623 & 114.690 & 133.801 & 111 & 319 & 492 \\
\hline
\end{tabular}

Sumber: Petri (2016) 
Tabel 10

Pengaruh TPP Terhadap Perdagangan dan Investasi (milyar dollar tahun 2015)

\begin{tabular}{|c|c|c|c|c|c|c|c|c|c|c|c|c|}
\hline \multirow{3}{*}{ Negara } & \multicolumn{4}{|c|}{ Ekspor } & \multicolumn{4}{|c|}{ Saham Masuk dari Investasi Asing Langsung } & \multicolumn{4}{|c|}{ Saham Keluar dari Investasi Asing Langsung } \\
\hline & \multicolumn{2}{|c|}{ Paduk } & \multicolumn{2}{|c|}{ TPP pada 2030} & \multicolumn{2}{|c|}{ Paduk } & \multicolumn{2}{|c|}{ TPP pada 2030} & \multicolumn{2}{|c|}{ Paduk } & \multicolumn{2}{|c|}{ TPP pada 2030} \\
\hline & 2015 & 2030 & Perubahan & Persentase & 2015 & 2030 & Perubahan & Persentase & 2015 & 2030 & Perubahan & Persentase \\
\hline Amerika & 3.274 & 5.693 & 469 & 8,2 & 5.792 & 9.348 & 250 & 2,7 & 7.028 & 11.768 & 169 & 1,4 \\
\hline Kanada* & 560 & 835 & 58 & 7,0 & 934 & 1.487 & 107 & 7,2 & 851 & 1.383 & 16 & 1,2 \\
\hline Chile* & 87 & 147 & 8 & 5,3 & 149 & 281 & 0 & 0,0 & 54 & 114 & 2 & 1,7 \\
\hline Meksiko * & 396 & 670 & 32 & 4,7 & 424 & 774 & 8 & 1,1 & 141 & 265 & 2 & 0,6 \\
\hline Peru* & 46 & 135 & 14 & 10,3 & 49 & 117 & 7 & 5,8 & 2 & 5 & 0 & 3,9 \\
\hline Amerika Serikat* & 2.184 & 3.906 & 357 & 9,1 & 4.236 & 6.690 & 128 & 1,9 & 5.980 & 10.002 & 149 & 1,5 \\
\hline Asia & 6.168 & 12.095 & 509 & 4,2 & 6.788 & 16.055 & 220 & 1,4 & 5.152 & 11.931 & 140 & 1,2 \\
\hline Brunei* & 10 & 16 & 1 & 9,0 & 0 & 0 & 0 & 11,3 & 7 & 18 & 1 & 3,3 \\
\hline Tiongkok & 2.339 & 4.976 & 9 & 0,2 & 3.078 & 8.153 & 19 & 0,2 & 750 & 2.064 & 8 & 0,4 \\
\hline Hong Kong & 199 & 357 & 4 & 1,0 & 1.452 & 3.069 & 8 & 0,3 & 2.253 & 5.485 & 15 & 0,3 \\
\hline India & 488 & 1.360 & 1 & 0,1 & 322 & 999 & 1 & 0,1 & 119 & 359 & 2 & 0,6 \\
\hline Indonesia & 205 & 446 & -4 & $-1,0$ & 233 & 621 & 5 & 0,8 & 22 & 58 & 1 & 1,1 \\
\hline Jepang* & 849 & 1.190 & 276 & 23,2 & 222 & 310 & 92 & 29,8 & 983 & 1.575 & 63 & 4,0 \\
\hline Korea & 623 & 1.089 & -11 & $-1,0$ & 177 & 327 & 1 & 0,2 & 277 & 628 & 2 & 0,3 \\
\hline Malaysia* & 261 & 491 & 99 & 20,1 & 128 & 279 & 48 & 17,2 & 140 & 345 & 24 & 7,0 \\
\hline Filipina & 74 & 184 & -1 & $-0,4$ & 60 & 145 & 1 & 0,5 & 13 & 38 & 0 & 0,3 \\
\hline Singapura* & 304 & 470 & 35 & 7,5 & 847 & 1.555 & 28 & 1,8 & 450 & 1.018 & 23 & 2,2 \\
\hline Taiwan & 348 & 506 & 4 & 0,8 & 41 & 69 & 0 & 0,7 & 69 & 155 & 1 & 0,7 \\
\hline Thailand & 275 & 561 & -9 & $-1,6$ & 176 & 386 & 1 & 0,2 & 66 & 179 & 1 & 0,4 \\
\hline Vietnam* & 161 & 357 & 107 & 30,1 & 40 & 108 & 16 & 14,4 & 2 & 4 & 0 & 7,2 \\
\hline Anggota ASEAN & 31 & 93 & -3 & $-2,8$ & 11 & 33 & $\mathbf{0}$ & 0,1 & 2 & 6 & $\mathbf{0}$ & 0,7 \\
\hline Oceania & 349 & 673 & 38 & 5,6 & 699 & 1.194 & 12 & 1,0 & 443 & 802 & 24 & 3,0 \\
\hline Australia* & 296 & 589 & 29 & 4,9 & 609 & 1.049 & 10 & 0,9 & 414 & 751 & 23 & 3,0 \\
\hline Selandia Baru* & 53 & 84 & 9 & 10,2 & 90 & 145 & 2 & 1,4 & 30 & 51 & 2 & 3,2 \\
\hline Negara Lainnya & 11.784 & 17.689 & 91 & 0,5 & 23.745 & 37.846 & 65 & 0,2 & 24.401 & 39.942 & 213 & 0,5 \\
\hline Uni Eropa & 7.472 & 9.706 & 49 & 0,5 & 17.526 & 26.052 & 48 & 0,2 & 19.780 & 30.566 & 169 & 0,6 \\
\hline Russia & 575 & 851 & 5 & 0,5 & 660 & 1.078 & 1 & 0,1 & 502 & 821 & 2 & 0,2 \\
\hline Negara lain & 3.736 & 7.132 & 37 & 0,5 & 5.559 & 10.716 & 17 & 0,2 & 4.119 & 8.555 & 41 & 0,5 \\
\hline Dunia & 21.575 & 36.149 & 1.106 & 3,1 & 37.025 & 64.443 & 547 & 0,8 & 37.025 & 64.443 & 547 & 0,8 \\
\hline \multicolumn{13}{|l|}{ Memo } \\
\hline Anggota TPP & 5.208 & 8.890 & 1.025 & 11,5 & 7.730 & 12.794 & 446 & 3,5 & 9.053 & 15.530 & 305 & 2,0 \\
\hline Non-anggota & 16.366 & 27.260 & 81 & 0,3 & 29.295 & 51.649 & 101 & 0,2 & 27.972 & 48.913 & 242 & 0,5 \\
\hline
\end{tabular}

Catatan: * Anggota TPP, Sumber: Petri (2016) 


\section{KESIMPULAN}

TPP berdasarkan hasil analisa permodelan ekonomi menunjukkan akan menguntungkan negara yang terlibat didalamnya, terlihat dengan meningkatnya PDB dari negara anggotanya. Selain itu, TPP juga meningkatkan lebih banyak arus investasi masuk daripada investasi keluar terutama investasi masuk yang berasal dari negara dengan perekonomian yang tinggi seperti Amerika Serikat, Jepang dan Uni Eropa. Posisi Indonesia berdasarkan hasil analisa Petri (2016) di tabel 9 terlihat tidak mengalami peningkatan perekonomian dalam waktu 15 tahun karena berada diluar TPP. Hal berbeda terjadi dengan negara lain di ASEAN anggota dari TPP yang mengalami pertumbuhan perekonomian yang pesat sedangkan tujuan dari Indonesia memperluas pangsa pasar ekspor di pasar prospektif dan hub perdagangan Internasional adalah untuk meningkatkan perekonomian nasional. Akan tetapi pendapat Deardorff (2013) yang menyatakan TPP tidak akan berpengaruh besar terhadap perekonomian negara nonTPP perlu juga diperhatikan. Hal ini karena Indonesia berdasarkan data ekspor migas dan non migas Indonesia pada tabel 1 menunjukkan, pasar utama dari produk Indonesia (migas dan non migas) adalah kawasan Asia dimana Indonesia sudah memiliki kesepakatan FTA dengan mereka. Sedangkan wilayah Amerika, ekspor non migas memiliki nilai yang tinggi dibandingkan ekspor migas. Jika Indonesia masuk dalam skema TPP maka ada tantangan yang perlu Indonesia hadapi terutama dalam hal kebijakan perdagangan, diantaranya transparansi, perlakuan yang sama untuk Badan Usaha Milik Negara (BUMN), perusahaan swasta dan tenaga kerja. Ada baiknya sebelum Indonesia terjun ke TPP, Indonesia memaksimalkan FTA yang ada. Langkah Indonesia melakukan kerjasama dengan Chile sudah tepat untuk melakukan penjajakan potensi pasar produk Indonesia ke negara dibenua Amerika sebelum terjun ke TPP. Namun, ada sejumlah tantangan yang perlu Indonesia hadapi dalam hal kebijakan perdagangan terutama dalam hal transparansi, perlakuan yang sama untuk Badan Usaha Milik Negara (BUMN), perusahaan swasta dan sebagainya.

\section{REFERENCES}

Badan Pusat Statistik (2016). Buletin Statistik Perdagangan Luar Negeri Ekspor Menurut Kelompok Komoditi dan Negara, Agustus 2016. Jakarta: Badan Pusat Statistik Indonesia.

Rencana Strategis Kementerian Perdagangan Tahun 2015 - 2019 (2015). Peraturan Menteri Perdagangan Republik Indonesia No 27/M-DAG/PER/4/2015 Tentang Rencana Strategis Kementerian Perdagangan Tahun 2015 - 2019.

Deardorff, A.V. (2013). Trade Implications of the Trans-Pacific Partnership for ASEAN and Other Asian Countries. The University of Michigan. Paper to be presented at 2nd 2013 Asian Development Review Conference 01-02 August 2013 Manila.

Hoang, N.V. (2015). The Regional Trade Agreements (RTAs) and Their Impact on Vietnam. Proceedings of the Second Asia-Pasific Conference on Global Business, Economics, Finance and Social Sciences (AP 15 Vietnam Conference). Danang, Vietnam, 10-12 July 2015. Paper ID :V525. 
Kawai, M., Wignaraja, G. (2010). Asian FTAs: Trends, Prospects, and Challenges. ADB Economics Working Paper Series. No.226. October 2010. Asian Development Bank, Philippines.Petri, P.A., Plummer, M.G., Fan, Z.(2011). The Trans-Pacific Partnership and Asia-Pacific Integration: A Quantitative Assessment. East-West Center Working Papers. Economics Series No. 119, October 24, 2011. Hawai'i.

Petri, P.A., Plummer, M.G. (2016). The Economic Effects of the Trans-Pacific Partnership: New Estimates. Peterson Institute for International Economics. Working Papers Series. WP 162. January 2016. https://piie.com/publications/wp/wp16-2.pdf

Williams, B.R. (2013). Trans-Pacific Partnership (TPP) Countries: Comparative Trade and Economic Analysis. Congressional Research Service. June 10, 2013.

Human Development Report (2015). Human Development Index (HDI) Chile. Diakses 7 Desember 2016 dari http://hdr.undp.org/sites/all/themes/hdr_theme/countrynotes/CHL.pdf

Office of the Chief Economist, Foreign Affairs and International Trade Canada (2013). The Economic Impact of the Canada - Chile Free Trade Agreement. Diakses pada 6 Desember 2016 dari http://www.international.gc.ca/economisteconomiste/assets/pdfs/research/canada_chile-canada_chili-eng.pdf

Finance and Development, a quarterly magazine of the IMF (2000), March 2000, Volume 37 No.1. Chile in the 1990s: Embracing Development Opportunities. Diakses pada 7 Desember 2016 dari http://www.imf.org/external/pubs/ft/fandd/2000/03/aninat.htm

Intracen (2014). ITC by Country. Report. Chile 05/12/2014. Diunduh pada tanggal 7 Desember 2016 dari http://www.intracen.org/country/chile/

Online (2016). Sumber dari Asia Regional Integration Center tentang perjanjian TPP Vietnam. Diakses pada tanggal 7 Desember 2016 dari https://aric.adb.org/fta-country

Online (2016). Sumber dari worldbank.org tentang Net ODA Receive (\% of GNI). Diakses pada $7 \quad$ Desember $2016 \quad$ dari http://data.worldbank.org/indicator/DT.ODA.ODAT.GN.ZS?end=2014\&locations=CL-ARUY-ZJ-PY-BO\&start=2014\&view=bar

Online (2016). Sumber dari worldbank.org tentang Nilai Tambah per sektor (dalam juta USD dan \% GDP) Chile dari tahun 2011 - 2015. Diunduh pada 7 Desember 2016 dari http://data.worldbank.org/indicator/NV.IND.TOTL.ZS?locations=CL

Online (2016). Sumber trademap.org tentang total impor Chile dari Indonesia dari 2011 hingga 2015. Diunduh pada tanggal 5 Desember 2016 dari http://trademap.org/Bilateral.aspx?nvpm=1|360||152||TOTAL|||2|1|1|2|1||1|1| 
Online (2016). Sumber trademap.org tentang total impor Chile dari Singapura dari 2011 hingga 2015. Diunduh pada tanggal 5 Desember 2016 dari http://trademap.org/Bilateral.aspx?nvpm=1|152||702||TOTAL|||2|1|1|1|1||1|1|1

Online (2016). Sumber trademap.org tentang total impor Chile dari Vietnam dari 2011 hingga 2015. Diunduh pada tanggal 5 Desember 2016 dari http://trademap.org/Bilateral.aspx?nvpm=1|152||704||TOTAL|||2|1|1|1|1||1|1| 